\title{
Mechanisms of the Gastric Antiulcerogenic Activity of Anacardium humile St. Hil on Ethanol-Induced Acute Gastric Mucosal Injury in Rats
}

Anderson Luiz-Ferreira ${ }^{1, *}$, Ana Cristina Alves de Almeida ${ }^{1}$, Maíra Cola ${ }^{1}$, Victor Barbastefano ${ }^{1}$, Ana Beatriz Albino de Almeida ${ }^{1}$, Leônia Maria Batista ${ }^{2}$, Elisângela Farias-Silva ${ }^{1}$, Cláudia Helena Pellizzon ${ }^{3}$, Clélia Akiko Hiruma-Lima ${ }^{4}$, Lourdes Campaner Santos ${ }^{5}$, Wagner Vilegas ${ }^{5}$ and Alba Regina Monteiro Souza Brito ${ }^{1}$

1 Departamento de Anatomia, Biologia Celular, Fisiologia e Biofísica, Instituto de Biologia, Universidade Estadual de Campinas, Campinas, SP, Brazil; E-Mails: aninhadabio@gmail.com (A-C.A.A.); mcola1@yahoo.com.br (M.C.); vicbio@yahoo.com (V.B.); anabia5@yahoo.com.br (A-B.A.A.); elisfarias.com@gmail.com (E.F-S); abrito@unicamp.br (A.R.M.S-B)

2 Laboratório de Tecnologia Farmacêutica, Universidade Federal da Paraíba - UFPB, Cx. Postal 5009, 58051-970, João Pessoa, PB, Brazil; E-Mail: leoniab@uol.com.br (L-M.B.)

3 Departamento de Morfologia, Instituto de Biociências, Universidade Estadual Paulista, Botucatu, SP, Brazil; E-Mail: claudia@ibb.unesp.br (C-H.P.)

4 Departamento de Fisiologia, Instituto de Biociências, Universidade Estadual Paulista, Botucatu, SP, Brazil; E-Mail: hiruma@ibb.unesp.br (C.A.H-L.)

5 Departamento de Química Orgânica, Instituto de Química, Universidade Estadual Paulista, Araraquara, SP, Brazil; E-Mails: loursant@iq.unesp.br (L-C.S.); vilegasw@gmail.com (W.V.)

* Author to whom correspondence should be addressed; E-Mail: domcarecone@yahoo.com.br.

Received: 9 September 2010; in revised form: 8 October 2010 / Accepted: 14 October 2010 / Published: 15 October 2010

Abstract: Leaves and bark infusions Anacardium humile St. Hil. (Anacardiaceae), known as in Brazil as "cajuzinho do cerrado", have been used in folk medicine as an alternative treatment for ulcers and gastritis. This study evaluated the gastroprotective activity of an ethyl acetate extract of the leaves of A. humile (AcF) and the mechanism involved in this gastroprotection. Pretreatment concentrations $\left(50,100,200 \mathrm{mg} \cdot \mathrm{kg}^{-1}\right)$ were administered by gavage. Following a $60 \mathrm{~min}$. period, all the rats were orally administered $1 \mathrm{~mL}$ of absolute ethanol. One hour after the administration of ethanol, all groups were sacrificed, and the gastric ulcer index was calculated. Prostaglandin $\mathrm{PGE}_{2}$ concentration, gastric adherent 
mucous, and the participation of nitric oxide (NO) and sulfhydryl compounds in the gastroprotection process were also analyzed using the most effective tested dose $\left(50 \mathrm{mg} \cdot \mathrm{kg}^{-1}\right)$. A histological study of the glandular stomach for the evaluation of the epithelial damage and mucus content was also performed. AcF significantly reduced the gastric damage produced by ethanol. This effect was statistically significant for the $50 \mathrm{mg} \cdot \mathrm{kg}^{-1}$ group compared to control. Also, it significantly increased the $\mathrm{PGE}_{2}$ (by 10fold) and mucous production, while pretreatment with NG-nitro-L-arginine methyl ester (LNAME) or $N$-ethylmaleimide (NEM) completely abolished the gastroprotection. AcF has a protective effect against ethanol, and this effect, might be due to the augmentation of the protective mechanisms of mucosa.

Keywords: Anacardium humile; antiulcer activity; cytoprotection; medicinal plants

\section{Introduction}

Numerous natural products derived from plant sources have been evaluated as therapeutics for the treatment of various diseases [1]. Among these diseases, peptic ulcers are a common disorder of the entire gastrointestinal tract that occur mainly in the stomach and the proximal duodenum. Despite great advances in the understanding of the peptic ulcer illness, its etiology has not been completely elucidated. The basic physiopathological concept is that the peptic ulcer results from an imbalance between some endogenous aggressive factor(s) [hydrochloric acid, pepsin, refluxed bile, leukotrienes, reactive oxygen species (ROS)] and cytoprotective factors, which include the function of the mucusbicarbonate barrier, surface active phospholipids, prostaglandins (PGs), mucosal blood flow, cell renewal and migration, nonenzymatic and enzymatic antioxidants and some growth factors [2-5].

Although recent advances in our understanding have highlighted the multi-factorial pathogenesis of peptic ulcers, secretion of gastric acid is still recognized as a central component of this disease. Therefore, the main therapeutic target is the control of this secretion using antacids, $\mathrm{H}_{2}$ receptor blockers (ranitidine, famotidine) or proton pump blockers (omeprazole and lansoprazole) [6]. However, nowadays gastric ulcer therapy faces a major drawback because most of the drugs currently available in the market show limited efficacy against gastric diseases and are often associated with severe side effects $[7,8]$.

In this context, the use of medicinal plants for the prevention and treatment of different pathologies is in continuous expansion all over the world, including the subject of this research [9]. Natural products are gaining space and importance in the pharmaceutical industry as well as inspiring the search for new potential sources of bioactive molecules [10,11].

Anacardium humile St. Hil. (Anacardiaceae), popularly known as "cajuzinho do cerrado" or "cajuí" is a shrub ( $\cong 30 \mathrm{~cm}$ tall), with very long roots, small flowers, a greenish calyx and red petals with stripes. The leaves and bark infusions are used in folk medicine as anti-emetics and diuretics, and as treatments for ulcers, gastritis and diarrhea [12-14]. In this regard, Anacardium humile St. Hil. extracts have shown to possess antiulcerogenic activity [15]. 
The aim of this work was to evaluate the pharmacological role of this species, describing the mechanism involved in the gastroprotective action of the ethyl acetate extract (AcF) of leaves of Anacardium humile St. Hil. in order to justify whether the traditional use of this medicinal species for ulcer, gastritis or diarrhea is justified.

\section{Results and Discussion}

Historically, natural products have provided an endless source of alternative drugs to medicine. Plant-derived products have dominated the human pharmacopoeia for thousands of years almost unchallenged [16]. In Brazil, a large number of herbal extracts are used in folk medicine to treat various types of digestive disorders [17], including the specie Anacardium humile.

The chromatographic profile of $A$. humile presented classes of compounds (Figures 1 and 2 and Table 1) which have beneficial effects on gastrointestinal ulcers [18], justifying the assessment of antiulcer activity and the mechanisms involved.

Examination of the chromatograms shown in Figure 2A led to the recognition of three classes of secondary metabolites in AcF (Table 1): gallic acid derivatives, catechins and flavonoids (flavonoid glysosides and biflavonoid). Flavonoid glycosides were better detected at $360 \mathrm{~nm}$ (Figure 2B). Determination of each class was accomplished using HPLC analyses and external calibration.

Figure 1. Compounds found in the leaves of Anacardium humile St. Hil.<smiles>O=C(O)c1cc(O)c(O)c(O)c1</smiles>

$\mathrm{R}$

$1 \mathrm{H}$

$2 \quad \mathrm{CH}_{3}$<smiles></smiles><smiles>Oc1cc(O)c2c(c1)O[C@H](c1ccc(O)c(O)c1)C(O)C2</smiles>

3<smiles>O=c1cc(-c2cc(O)cc(-c3c(O)cc(O)c4c(=O)cc(-c5ccc(O)c(O)c5)oc34)c2)oc2cc(O)cc(O)c12</smiles>

$$
\begin{array}{ll} 
& \text { R } \\
\mathbf{4} & \text { O-gllo } \\
\mathbf{5} & \text { O-gal } \\
\mathbf{6} & \text { O-glc }(1 \rightarrow 6) \text { rha }
\end{array}
$$


Figure 2. A. HPLC chromatographic profile of the $\mathrm{AcF}$ from A. humile monitored at $210 \mathrm{~nm}$. 1. Gallic acid, a. Unknown, b. Unkown catechin, 2. Methyl gallate, 3. (+)catechin, c. Gallic acid derivative, 7. Amenthoflavone, * Flavonoid glycosides and gallic acid derivatives. B. Elution monitored at $360 \mathrm{~nm}$ for flavonol glycosides.
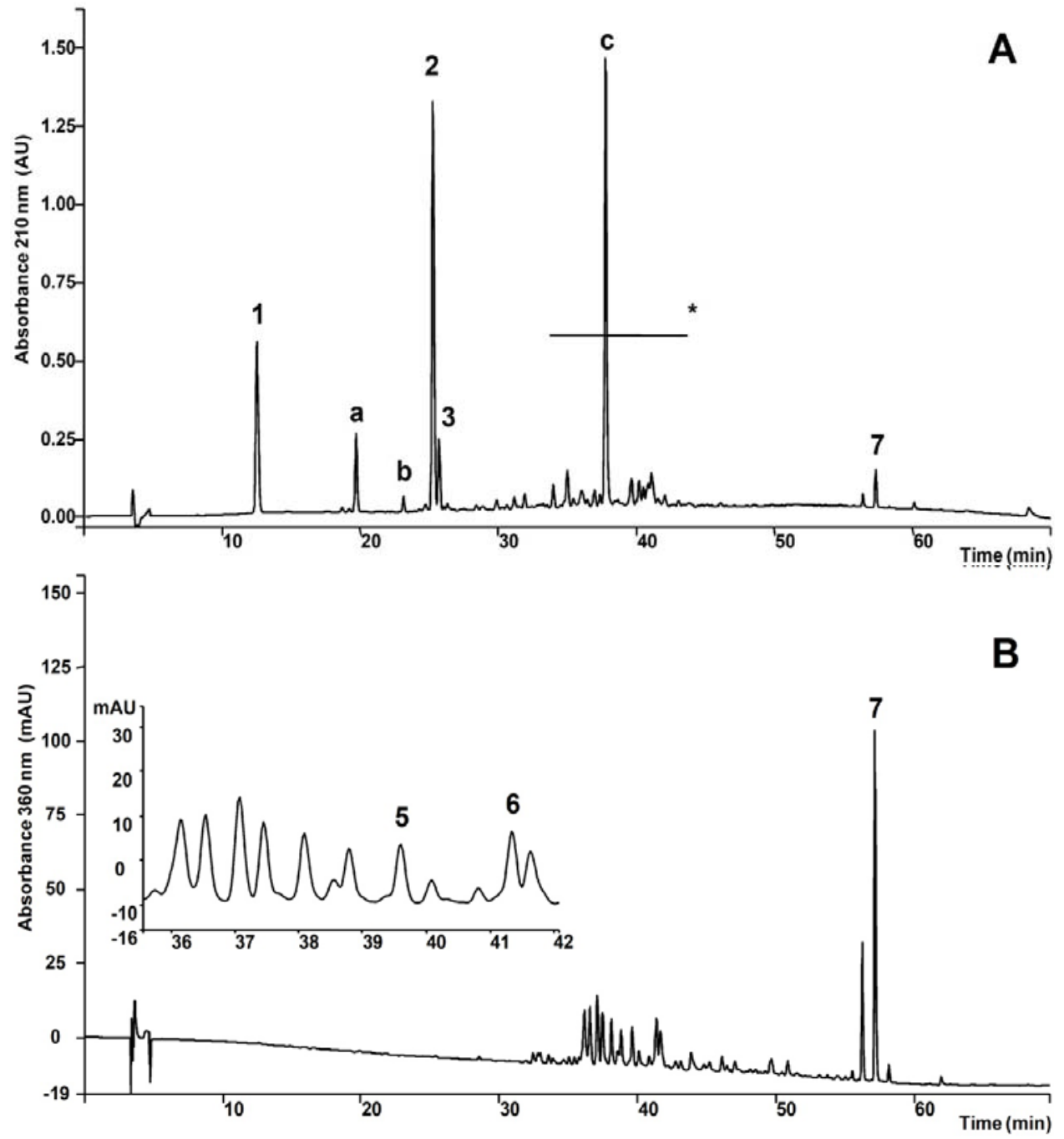

Table 1. Concentration of the secondary metabolites present in the AcF from A. humile St. Hil.

\begin{tabular}{lr}
\hline Substance or class & Concentration \pm SD $\left(\mathbf{m g}^{\mathbf{1}} \mathbf{- 1}\right)$ \\
\hline Gallic acid derivatives & \\
Gallic acid & $103.08 \pm 0.64$ \\
Methyl gallate & $228.04 \pm 1.11$ \\
Unknown gallic acid derivatives & $329.59 \pm 3.65$ \\
Total & $728.71 \pm 3.78$ \\
Catechins & \\
(+)-Catechin & $21.14 \pm 0.45$ \\
Unknown catechins & $4.34 \pm 0.08$ \\
Total & $29.70 \pm 0.46$ \\
Flavonoids & \\
Amenthoflavone & $29.33 \pm 0.82$ \\
Unknown flavonoids & $92.76 \pm 0.75$ \\
Total & $122.09 \pm 1.07$ \\
\hline
\end{tabular}


The effect of ethyl acetate extract from Anacardium humile (AcF), on gastric ulcers induced by an irritant agent (absolute ethanol) was investigated in rats. Pre-treatment with AcF and lansoprazole were found to inhibit ethanol-induced gastric mucosal injury. This inhibitory effect of AcF was the highest and statistically significant in the $50 \mathrm{mg} \cdot \mathrm{kg}^{-1}$ group. The groups treated with $100 \mathrm{mg} \cdot \mathrm{kg}^{-1}$ and $200 \mathrm{mg} \cdot \mathrm{kg}^{-1}$ of $\mathrm{AcF}$, showed insignificant inhibitory effects for ethanol-induced gastric mucosal injury. Therefore, with the purpose of investigating the probable gastroprotective mechanisms involved in the action promoted by AcF, we studied only a dose of $50 \mathrm{mg} \cdot \mathrm{kg}^{-1}$ for its efficacy. At the same time, $30 \mathrm{mg} \cdot \mathrm{kg}^{-1}$ of lansoprazole significantly inhibited ethanol-induced gastric lesions compared to the control. The obtained results suggested that the ethyl acetate extract of A. humile posses a significant antiulcer effect in these ulcer-induced models.

Table 2. Effects of orally administered ethyl acetate extract (AcF; 50, 100 and 200 mg.kg ${ }^{-1}$ ) obtained from the leaves of $A$. humile St. Hil. on ethanol-induced gastric ulcers in rats.

\begin{tabular}{llcc}
\hline Models & \multicolumn{1}{c}{$\begin{array}{c}\text { Groups } \\
(\mathbf{n}=\mathbf{7})\end{array}$} & $\begin{array}{c}\text { Ulcer index } \\
(\text { mean } \pm \text { SD) }\end{array}$ & $\begin{array}{c}\text { Inhibition } \\
(\mathbf{\%})\end{array}$ \\
\hline Ethanol & Vehicle & $34.4 \pm 14.2$ & - \\
& $50 \mathrm{mg} \cdot \mathrm{kg}^{-1} \mathrm{AcF}$ & $11.6 \pm 6.6^{\mathrm{a}}$ & 66.2 \\
& $100 \mathrm{mg} \cdot \mathrm{kg}^{-1} \mathrm{AcF}$ & $22.8 \pm 12.6$ & 33.7 \\
& $200 \mathrm{mg} \cdot \mathrm{kg}^{-1} \mathrm{AcF}$ & $31.4 \pm 10.5$ & 8.7 \\
& $30 \mathrm{mg} \cdot \mathrm{kg}^{-1}$ lansoprazole & $1.5 \pm 0.8^{\mathrm{a}}$ & 95.6 \\
\hline
\end{tabular}

The columns are the mean \pm S.D. of six rats. Different letters indicate significant differences. ANOVA: $\mathrm{F}_{(4,22)}=8.521(\mathrm{p}<0.05$, Tukey test $)$.

EtOH-induced ulcers were not inhibited by antisecretory agents such as cimetidine, but are inhibited by agents that exhibit a gastroprotective action with an anti-oxidative cytoprotection [19]. Results of the present study showed that AcF $\left(50 \mathrm{mg} \cdot \mathrm{kg}^{-1}\right)$ provided protection against gastric ulcers induced by ethanol (Table 2 and Figure 3C). Ethanol-induced ulceration is inhibited by agents that enhance mucosal defensive factor [19,20]. Since AcF enhanced mucosal defensive factors $\left(\mathrm{PGE}_{2}\right.$ and mucus), this increase of the defensive factors promoted by the AcF may be, at least partially, one of the possible mechanisms by which AcF ameliorated the ethanol-induced gastric damage.

Figure 3. Photomicrography of stomach gastric ulceration caused by ethanol.
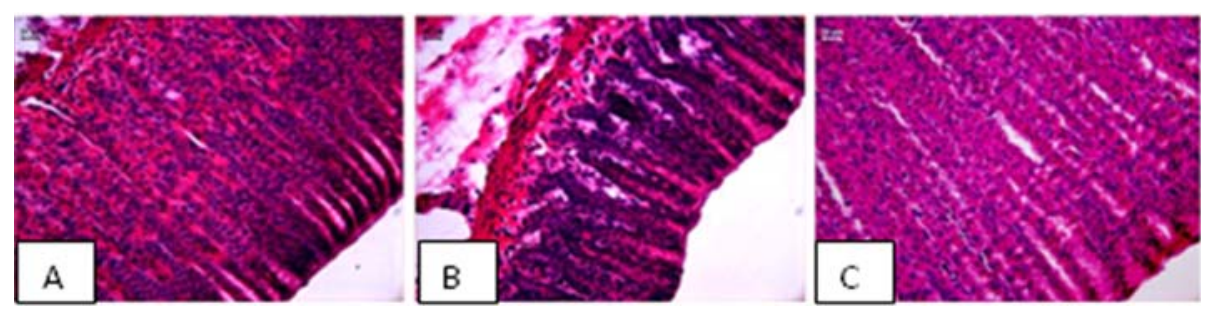

Gastric mucosal layer of rats stained with HE showing (A) normal epithelium from control rats;

(B) damaged epithelium from Tween treatment and (C) repaired epithelium after AcF treatment.

Aiming to investigate the probable gastroprotective mechanisms involved in the action promoted by this extract, we evaluated the role of $\mathrm{AcF}$ on $\mathrm{PGE}_{2}$ production. Pretreatment of rats with indomethacin 
markedly reduced the gastric mucosal prostaglandin contents (Figure 4). On the other hand, pretreatment of rats with $\mathrm{AcF}\left(50 \mathrm{mg} \cdot \mathrm{kg}^{-1}\right)$ induced drastic increase of $\mathrm{PGE}_{2}$ levels as compared to rats treated only with Tween $(\mathrm{P}<0.01)$.

Figure 4. Effects of orally administered ethyl acetate extract (AcF; $50 \mathrm{mg} \cdot \mathrm{kg}^{-1}$ ) obtained from the leaves of A. Humile St. Hil. and indomethacin on gastric prostaglandin $\mathrm{E}_{2}\left(\mathrm{PGE}_{2}\right)$ production in rats.
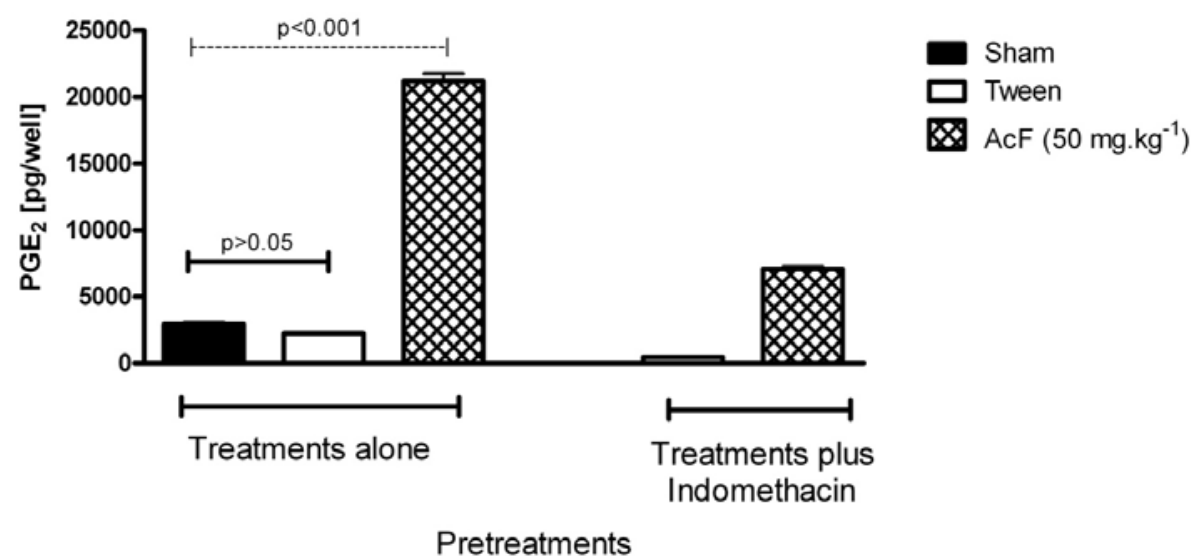

The columns are the mean \pm S.D of five rats. ANOVA: $F_{(4,20)}=144.6(p \leq 0.05$, Tukey test).

Continuous generation of $\mathrm{PGE}_{2}$ by the mucosa is crucial for the maintenance of mucosal integrity and protection against ulcerogenic and necrotizing agents [21]. Almost all of the mucosal defense mechanisms are stimulated and/or facilitated by PGs. Our data suggest that the cytoprotective action of $\mathrm{AcF}$ on the gastric mucosa may be related to an increase in $\mathrm{PGE}_{2}$ production. PGs inhibit acid secretion, stimulate mucus, bicarbonate, and phospholipid secretion; increase mucosal blood flow; and accelerate epithelial restitution and mucosal healing [21].

We also observed the effect of AcF on adherent mucus production by the gastric mucosa (Figure 5). Pretreatment with AcF (50 mg. $\left.\mathrm{kg}^{-1}\right)$ and carbenoxolone $\left(200 \mathrm{mg} \cdot \mathrm{kg}^{-1}\right)$ induced significant increase in mucoprotective effect in animals submitted to pylorus ligature.

Figure 5. Effects of orally administered ethyl acetate extract (AcF; $50 \mathrm{mg} \cdot \mathrm{kg}^{-1}$ ) obtained from the leaves of $A$. humile St. Hil. and of carbenoxolone $\left(200 \mathrm{mg} \cdot \mathrm{kg}^{-1}\right)$ on adherent gastric mucous (measured as the amount of alcian blue bound) in pylorus-ligated rats.

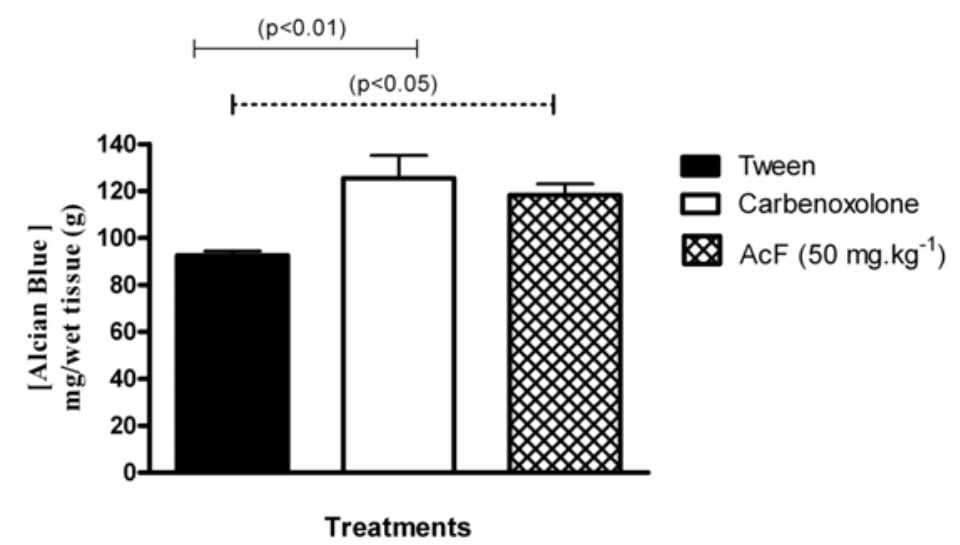

The columns are the mean \pm S.D. of five rats. ANOVA: $\mathrm{F}_{(2,12)}=7.455(\mathrm{p}<0.05$, Tukey test $)$. 
Gastric mucus is an important protective factor for the gastric mucosa and consists of a viscous, elastic, adherent and transparent gel formed by water and glycoproteins that covers the entire gastrointestinal mucosa. The protective properties of the mucus barrier depend not only on the gel structure but also on the amount or thickness of the layer covering the mucosal surface [22]. In the present study, we also measured gastric adherent mucus and, the production was increased in AcF $\left(50 \mathrm{mg} \cdot \mathrm{kg}^{-1}\right.$ ) (Figures 5 and 6C). Furthermore, our findings that AcF stimulated mucus secretion support the notion that this fraction acted by stimulating $\mathrm{PGE}_{2}$ production (Figure $7 \mathrm{C}$ ). It has been previously reported that $\mathrm{PGE}_{2}$ stimulates mucus secretion [22]. The mucus layer protects the newly formed cells against damage caused by acid $\mathrm{pH}$ and the proteolytic potential of the gastric secretions [23].

Figure 6. Photomicrography of stomach showing the mucosal layer stained with PAS showing mucus in (A) normal epithelium; (B) loss of epithelial mucus in Tween treatment and (C) presence of epithelial mucus after AcF treatment.

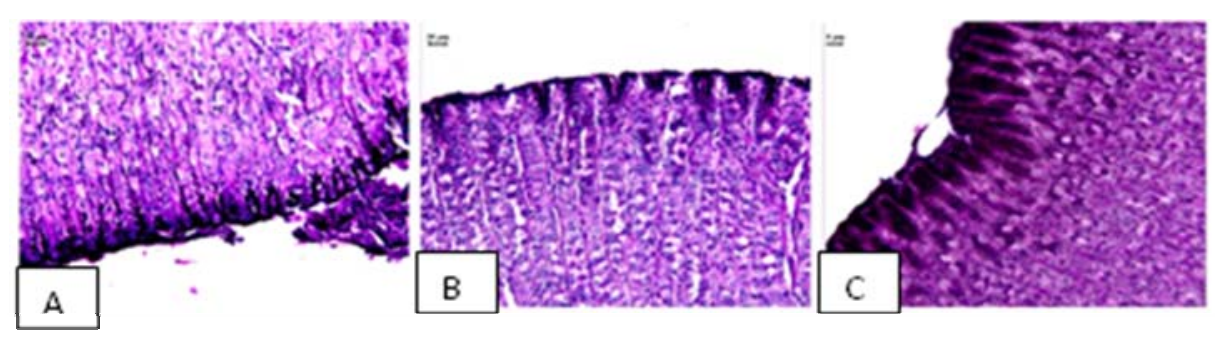

Vascular changes in gastric mucosa appeared to be the most pronounced feature of absolute ethanol-induced injury [24]. As shown in Figure 7, pretreatment with NG-nitro-L-arginine methyl ester (L-NAME) $\left(70 \mathrm{mg} \cdot \mathrm{kg}^{-1}\right.$, i.p.) attenuated the gastroprotection of both AcF $\left(50 \mathrm{mg} \cdot \mathrm{kg}^{-1}\right)$ and carbenoxolone $\left(100 \mathrm{mg} \cdot \mathrm{kg}^{-1}\right)$.

Figure 7. Effects of orally administered ethyl acetate extract (AcF; $50 \mathrm{mg} \cdot \mathrm{kg}^{-1}$ ) obtained from the leaves of $A$. humile St. Hil. and of carbenoxolone $\left(100 \mathrm{mg} \cdot \mathrm{kg}^{-1}\right)$ on ethanolinduced gastric ulcers in rats pretreated with L-NAME.

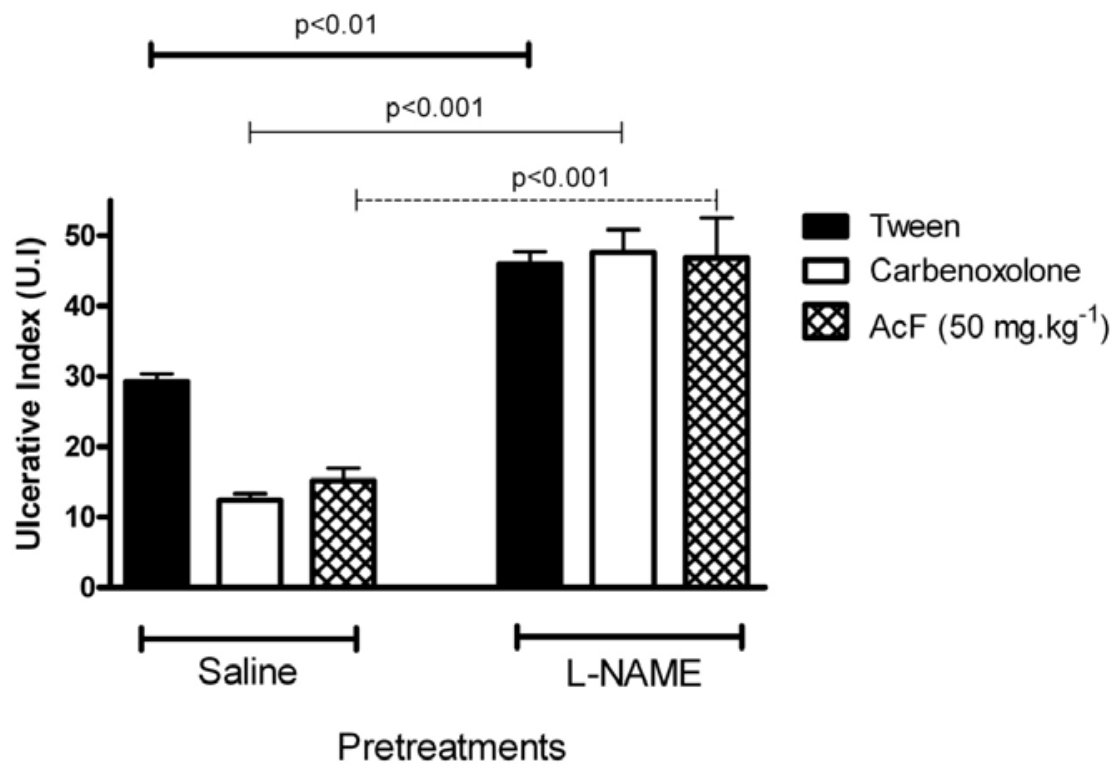

The columns are the mean \pm S.D. of five rats. ANOVA: $\mathrm{F}_{(5,28)}=18.89(\mathrm{p}<0.05$, Tukey test $)$. 
Nitric oxide (NO) synthesis or exogenously given NO has been repeatedly shown to protect the gastric mucosa against damage induced by various agents [25]. It has been reported that the serum and local NO levels are reduced in gastric injury models induced by ethanol and indomethacin, suggesting that the decrease in local NO content might be a key factor in facilitating gastric mucosal injury [26]. The previous administration of L-NAME, an NO-synthase inhibitor, altered the cytoprotection induced by AcF, suggesting that the anti-ulcer activity of this fraction is through the participation of endogenous nitric oxide. The role of NO in gastroprotection has been widely accepted [27]. An increase in NO levels by L-arginine (a substrate for NOS), but not D-arginine, has been shown to reduce absolute ethanol- induced gastric lesions [28].

It is well known that reduced glutathione GSH protects the gastric mucosa submitted to an ulcerative challenge [29]. $\mathrm{N}$-Ethylmaleimide (NEM, $10 \mathrm{mg} \cdot \mathrm{kg}^{-1}$, s.c.)-pretreated rats produced a reduction in the gastroprotection exerted by the administration of $\mathrm{AcF} 50 \mathrm{mg} \cdot \mathrm{kg}^{-1}$ on ethanol-induced gastric hemorrhagic lesions (Figure 8). A significant decrease in gastric GSH following ethanol administration indicated massive generation of free radicals [30]. Our result is in agreement with earlier reports showing depletion of sulfhydryls in ethanol-induced gastric lesions [31]. In this respect, the present increase of tissue damage, evoked by ethanol in the NEM pretreated rats, was expected because the treatment with glutathione depletors has been shown to significantly potentiate ulcerogeninduced gastric mucosal injury [32], whereas an increase in mucosal NP-SH exerts a gastroprotective effect [33]. In this context, the antiulcerogenic activity of $\mathrm{AcF}\left(50 \mathrm{mg} \cdot \mathrm{kg}^{-1}\right)$ may depend on mucosal GSH levels, and it is likely that an increase of endogenous sulfhydryl compounds play an important role in the gastroprotective properties of this fraction.

Figure 8. Effects of orally administered ethyl acetate extract (AcF; $50 \mathrm{mg} \cdot \mathrm{kg}^{-1}$ ) obtained from the leaves of $A$. humile St. Hil. and of carbenoxolone $\left(100 \mathrm{mg} \cdot \mathrm{kg}^{-1}\right)$ on ethanolinduced gastric ulcers in rats pretreated with NEM.

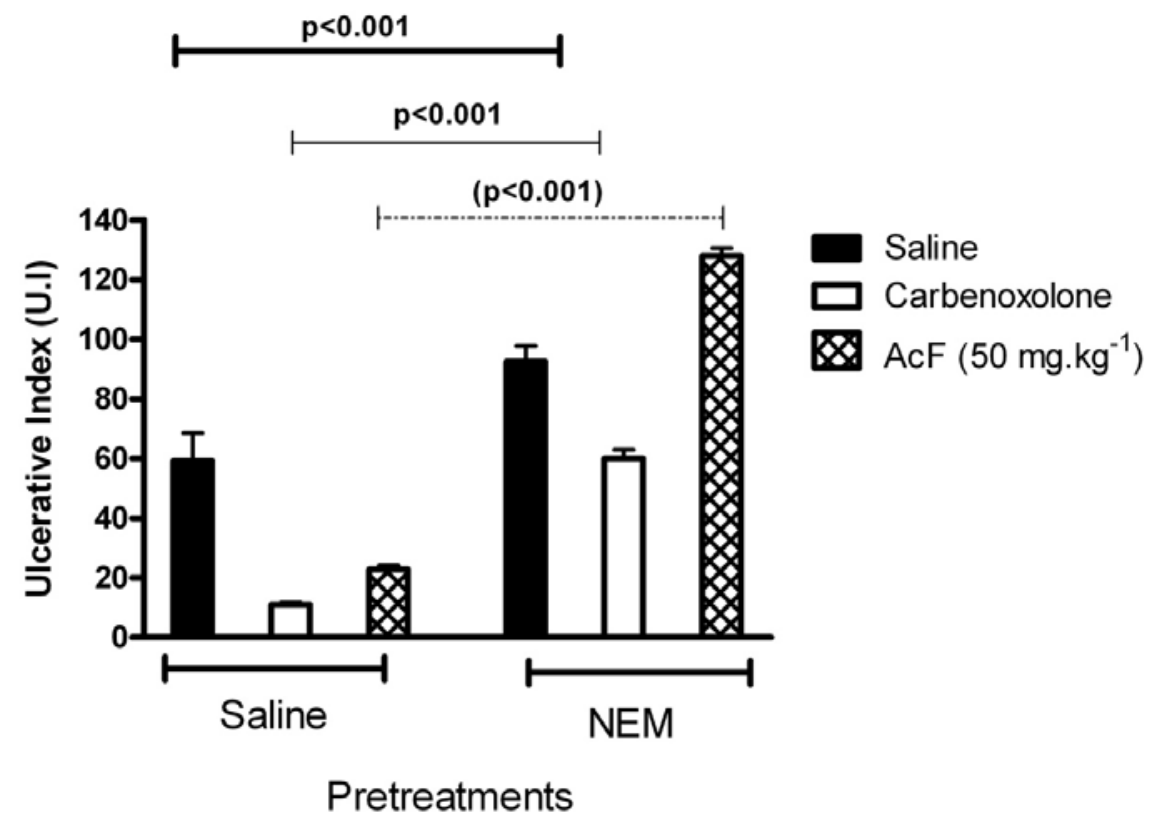

The columns are the mean \pm S.D. of five rats. ANOVA: $\mathrm{F}_{(5,24)}=242.6(\mathrm{p}<0.05$, Tukey test). 


\section{Experimental}

\section{Plant material, extraction and isolation}

A. humile St. Hil. was collected along Monte do Carmo road, in Porto Nacional in Tocantins state, Brazil in November 2002. The plants were identified by Marcos Alves and Eduardo Ribeiro of the University of Tocantins and a voucher specimen (accession number 1922) was deposited in the University of Tocantins Herbarium.

Air-dried and powdered leaves $(650 \mathrm{~g})$ of A. humile St. Hil. were exhaustively extracted by successive maceration at room temperature with dichloromethane (DCM, $5 \mathrm{~L})$ and methanol $(\mathrm{MeOH}$, 5 L) $\left(130: 1, \mathrm{w} / \mathrm{v}\right.$, one week for each solvent). Solvents were evaporated at $60{ }^{\circ} \mathrm{C}$ under reduced pressure to yield the $\mathrm{DCM}(6 \mathrm{~g})$ and $\mathrm{MeOH}(193 \mathrm{~g})$ extracts. A portion of the $\mathrm{MeOH}$ extract $(80 \mathrm{~g})$ was partitioned between a mixture of EtOAc/water $(5 \mathrm{~L}, 1: 1, \mathrm{v} / \mathrm{v})$ to yield $3.4 \mathrm{~g}$ of EtOAc fraction (AcF) and $74 \mathrm{~g}$ of aqueous fraction (AqF). Flavonoids were detected in $\mathrm{AcF}$ as described elsewhere [34].

A portion $(1 \mathrm{~g})$ of the $\mathrm{MeOH}$ extract of A. humile St. Hil. was fractionated by gel permeation chromatography on a Sephadex LH-20 (Pharmacia) column $(5 \mathrm{~cm} \times 100 \mathrm{~cm})$ and eluted with $\mathrm{MeOH}$ (flow rate $\left.0.5 \mathrm{~mL} \cdot \mathrm{min}^{-1}\right)$. One hundred fractions $(5 \mathrm{~mL}$ each) were collected and checked by Thin Layer Chromatography (TLC) on silica gel plates eluted with a mixture of $\mathrm{CHCl}_{3} / \mathrm{MeOH} / \mathrm{n}-\mathrm{PrOH} / \mathrm{H}_{2} \mathrm{O}$ (5:6:1:4; lower phase) and developed either with Natural Products - Polyethyleneglycol Reagent or with anisaldehyde/sulfuric acid solution [34]. The fractions were subsequently combined and then purified by HPLC using a Knauer Chance system equipped with a Waters R401 refractive index detector, a Phenomenex Luna reverse-phase RP 18 column $(25 \mathrm{~cm} \times 1 \mathrm{~cm} \times 10 \mu \mathrm{m})$ and a Rheodyne injector with a $100 \mu \mathrm{l}$ sample loop. $\mathrm{MeOH}-\mathrm{H}_{2} \mathrm{O}(8: 2, \mathrm{v} / \mathrm{v})$ was used as the eluent (flow rate $\left.2 \mathrm{~mL} \cdot \mathrm{min}^{-1}\right)$. Fractions $64-72(150 \mathrm{mg})$ yielded gallic acid $(1,50 \mathrm{mg})$ and methyl gallate $(2,75 \mathrm{mg})$; fractions 98-103 (75 mg) yielded $(+)$-catechin (3, $50 \mathrm{mg})$; fractions 119-124 (35 mg) yielded quercetin-3-O- $\beta$-D-allopyranoside $(4,5 \mathrm{mg})$ and quercetin-3-O- $\beta$-D-galactopyranoside $(5,8 \mathrm{mg}$ ); fractions $144-149$ (35 mg) yielded quercetin-3-O- $\alpha$-L-rhamnopyranosyl-(1 $\rightarrow 6)$ - $\beta$-D-glucopyranoside (rutin, 6, $8 \mathrm{mg}$ ); and fractions 178-200 (200 mg) yielded the biflavonoid amentoflavone (7, $165 \mathrm{mg}$ ) (Figure 1).

The chemical identification of substances (1-7) was established by Nuclear magnetic resonance Nuclear magnetic resonance (NMR) spectra in DMSO- $\mathrm{d}_{6}$ using a Varian INOVA 500 spectrometer operated at $500 \mathrm{MHz}$ for ${ }^{1} \mathrm{H}$ and $150 \mathrm{MHz}$ for ${ }^{13} \mathrm{C}$. The 2D analyses included ${ }^{1} \mathrm{H}-{ }^{1} \mathrm{H}-\mathrm{COSY}$ (chemical shift correlation spectroscopy), inverse-detected ${ }^{1} \mathrm{H}_{-}{ }^{13} \mathrm{C}$ HSQC (heteronuclear single quantum coherence) and HMBC (heteronuclear multiple bond connectivity). All of the spectral data of the substances (1-7) were compared to those reported in the literature [35,36].

The chromatographic profile of AcF was obtained using an HPLC system (ProStar, Varian) equipped with a ProStar 330 photodiode-array ultraviolet detector (PDA), a Rheodyne injector $(20 \mu \mathrm{L})$, a Phenomenex Luna RP-18 column $(250 \times 4.6 \mathrm{~mm}$ i.d. $5 \mu \mathrm{m})$ and a RP-18 Phenomenex guard column $(4 \times 4.6 \mathrm{~mm}$, i.d. $5 \mu \mathrm{m})$. Elution was performed with a linear gradient of water $(\mathrm{A})$ and acetonitrile (B) (with $0.05 \%$ of trifluoroacetic acid) from 23 to $30 \%$ of B in 5 min, then from 30 to $48 \%$ of $\mathrm{B}$ in $40 \mathrm{~min}$ and then from 48 to $100 \%$ of $\mathrm{B}$ in $65 \mathrm{~min}$. Flow rate was $1.0 \mathrm{~mL} \cdot \mathrm{min}^{-1}$ and effluent was monitored at $210 \mathrm{~nm}$ and at $360 \mathrm{~nm}$. 
The determination of the concentration of the metabolites present in AcF was performed using external calibration. Flavonoids were expressed based on rutin, in the calibration range between $5-500 \mu \mathrm{g} \cdot \mathrm{mL}^{-1}\left(\mathrm{y}=-4.81 \cdot 10^{5}+1.91 \cdot 10^{5} \mathrm{x}, \mathrm{R}=0.9999, \mathrm{~N}=6\right)$; gallic acid derivatives were expressed based on gallic acid, in the calibration range between $2-200 \mu \mathrm{g} \cdot \mathrm{mL}^{-1}\left(\mathrm{y}=-9.69 \cdot 10^{4}+2.38 \cdot 10^{5} \times\right.$, $\mathrm{R}=0.9998, \mathrm{~N}=9$ ); catechins were expressed in terms of $(+)$-catechin, in the calibration range between $1-70 \mu \mathrm{g} \cdot \mathrm{mL}^{-1}\left(\mathrm{y}=1.40 \cdot 10^{5}+8.93 \cdot 10^{5} \mathrm{x}, \mathrm{R}=0.9999, \mathrm{~N}=6\right)$.

\section{Animals}

Male Wistar rats (180-250 g) obtained from the breeding colony at the Universidade Estadual de Campinas (CEMIB/UNICAMP) were used. The animals were housed in a $12 \mathrm{~h}$ light/dark cycle, at a humidity of $60 \pm 10 \%$ and a temperature of $21.5 \pm 1.0^{\circ} \mathrm{C}$ and were fed a certified Nuvilab CR-a ${ }^{\circledR}$ (Nuvital) diet, with free access to tap water. All experiments were carried out in the morning. The experimental protocols were all approved of by the Institutional Committee for Ethics in Animal Experimentation (no. 538-1, CEEA/IB/UNICAMP).

\section{Drugs}

Lansoprazole (Medley, Campinas, SP, Brazil), carbenoxolone and Tween $80^{\circledR}$ (Sigma Chemical Co., St. Louis, MO, USA.) were used in this study. The reagents for buffers and other solutions were all of analytical grade. All the other chemicals and reagents used in this study were of analytical grade.

\section{Ethanol-induced gastric lesion in rats}

After a total of $24 \mathrm{~h}$ fasting, three groups of rats $(\mathrm{n}=5)$ received an oral administration of AcF (50, $\left.100,200 \mathrm{mg} \cdot \mathrm{kg}^{-1}\right)$, lansoprazole $\left(30 \mathrm{mg} \cdot \mathrm{kg}^{-1}\right)$ or vehicle $\left(10 \mathrm{~mL} \cdot \mathrm{kg}^{-1}\right)$. One hour after treatment, all rats received, orally, $1 \mathrm{~mL}$ of $99.5 \%$ ethanol to induce gastric ulcers [20]. The animals were killed by $\mathrm{CO}_{2}$ gas $1 \mathrm{~h}$ after treatment with the ulcerogenic agent and the stomachs removed to determine the gastric damage. The stomachs were removed, opened along the greater curvature and fixed between two glass plates. Ulcerative lesion was calculated according to the methodology described by Szelenyi and Thiemer [37].

\section{Determination of prostaglandin $P G E_{2}$ synthesis}

Thirty minutes after treatment with indomethacin $\left(30 \mathrm{mg} \cdot \mathrm{kg}^{-1}\right)$, vehicle $\left(10 \mathrm{~mL} \cdot \mathrm{kg}^{-1}\right)$ or $\mathrm{AcF}$ $\left(50 \mathrm{mg} \cdot \mathrm{kg}^{-1}\right.$ ), the rats were killed by $\mathrm{CO}_{2}$ gas and their abdomen opened. The control group without treatment experienced the same general conditions of the experimental groups. Samples of the corpus (full thickness) were excised, weighed and suspended in $1 \mathrm{~mL}$ of $10 \mathrm{mM}$ sodium phosphate buffer, $\mathrm{pH}$ 7.4. After homogenizing with a Polytron ${ }^{\circledR}$ PT 10-35 homogenizer (Kinematica AG, Lucerne, Switzerland), the homogenate was incubated in a Dubnoff water-bath (Tecnal, Piracicaba, Brazil) at $37^{\circ} \mathrm{C}$ for $20 \mathrm{~min}$ and the amount of $\mathrm{PGE}_{2}$ in the buffer was measured by enzyme immunoassay using a commercial kit (RPN222, Amersham). The absorbance was read at $450 \mathrm{~nm}$ and the amount of $\mathrm{PGE}_{2}$ expressed as pg/wet weight of tissue, was determined from a standard curve of $\mathrm{PGE}_{2}$ [38]. 


\section{Determination of mucus in gastric content}

After rats $(\mathrm{n}=6-7)$ had fasted for $24 \mathrm{~h}$, under anesthesia, the abdomen was incised and the pylorus ligated. The vehicle (Tween), carbenoxolone $\left(200 \mathrm{mg} \cdot \mathrm{kg}^{-1}\right)$ or AcF $\left(50 \mathrm{mg} \cdot \mathrm{kg}^{-1}\right)$ was administered orally after the pylorus ligature. The animals were killed by $\mathrm{CO}_{2}$ gas $4 \mathrm{~h}$ after the drug treatments. The stomach content was immersed in $10 \mathrm{~mL} 0.02 \%$ Alcian blue in $0.16 \mathrm{M}$ sucrose/0.05 M sodium acetate, $\mathrm{pH} 5.8$, and incubated for $24 \mathrm{~h}$ at $20^{\circ} \mathrm{C}$. The Alcian blue binding extract was centrifuged at $2000 \times \mathrm{g}$ for $10 \mathrm{~min}$. The absorbance of supernatant was measured at $615 \mathrm{~nm}$ using a light spectrophotometer U/2000 (Hitachi, Japan). The free mucus in the gastric content was calculated from the amount of Alcian blue binding [mg/wt tissue (g)] [39].

\section{Ethanol-induced gastric lesion in NEM and L-NAME- pretreatment rats}

Rats were divided into groups of 6-7 animals that fasted for $24 \mathrm{~h}$. They had previously been treated intraperitoneally with NEM ( $N$-ethylmaleimide, Sigma, USA) at a dose of $10 \mathrm{mg} \cdot \mathrm{kg}^{-1}$, L-NAME (NGnitro-L-arginine methyl ester, Sigma, USA) at a dose of $70 \mathrm{mg} \cdot \mathrm{kg}^{-1}$ or saline. Thirty minutes later, the groups received an oral dose of the vehicle, carbenoxolone $\left(100 \mathrm{mg} \cdot \mathrm{kg}^{-1}\right)$ or AcF $\left(50 \mathrm{mg} \cdot \mathrm{kg}^{-1}\right)$. After $60 \mathrm{~min}$, all groups were treated orally with $1 \mathrm{~mL}$ of absolute ethanol for gastric-ulcer induction [40]. Animals were killed by $\mathrm{CO}_{2}$ gas $1 \mathrm{~h}$ after ethanol administration and the stomachs excised and gastric damage determined as described above.

\section{Histology of ethanol-induced gastric lesions}

The stomach of the rats submitted to gastric ulcers in the ethanol model with different treatments (control, carbenoxolone and AcF) were pushed off and opened by the large curvature and the lesion was localized. The lesion was sectioned, and one sample was fixed in ALFAC solution (alcohol, chloroform and acetic acid) for $24 \mathrm{~h} \mathrm{in} 4{ }^{\circ} \mathrm{C}$. The samples were routinely processed for embedding in paraplast, and cut into $7 \mu \mathrm{m}$ thick section. These sections were stained with hematoxylin-eosin [41] and periodic acid -Schiff (PAS) [42]. The samples were analysed with a Leica microscope associated with Leica Qwin Software (Leica-England).

\section{Statistical analysis}

The results were expressed as the mean \pm S.D. Statistical significance among groups was assessed by one-way analysis of variance (ANOVA) followed by the Tukey tests, with $p \leq 0.05$ indicating significance. All statistical analyses were done using Prism software (GraphPad, San Diego, CA, USA).

\section{Conclusions}

In conclusion, only a limited number of studies have reported the biological effects of Anacardium humile St. Hil., which has made it difficult to find references, including those describing antiulcerogenic activity, first reported by our research group in a previous study. The present investigation attempted to evaluate in more depth the anti-ulcerogenic mechanism of the ethyl acetate extract of this 
plant. The gastroprotective mechanism is based on its ability to strengthen defensive factors by elevating mucus and $\mathrm{PGE}_{2}$ levels with participation of $\mathrm{NO}$ and $\mathrm{SH}$ groups to prevent or attenuate the ulcer process. Therefore, the results obtained from the administration of AcF of Anacardium humile under in vivo models support the ethnopharmacological use of this species.

\section{Acknowledgement}

We thank Fundação de Amparo à Pesquisa do Estado de São Paulo (FAPESP) for financial support, to the Coordenação de Aperfeiçoamento de Pessoal de Nível Superior (CAPES) for a fellowship to AL-F and to Conselho Nacional de Desenvolvimento Científico e Tecnológico for the grants to ARMSB and WV.

\section{References}

1. de Sousa Falcão, H.; Leite, J.A.; Barbosa-Filho, J.M.; de Athayde-Filho, P.F.; de Oliveira Chaves, M.C.; Moura. M.D.; Ferreira, A.L.; de Almeida, A.B.; Souza-Brito, A.R.; de Fátima Formiga Melo Diniz, M.; Batista, L.M. Gastric and duodenal antiulcer activity of alkaloids: A review. Molecules 2008, 12, 3198-3223.

2. Bandyopadhyay, D.; Biswas, K.; Bhattacharyya, M.; Reiter, R.J.; Banerjee, R.K. Gastric toxicity and mucosal ulceration induced by oxygen-derived reactive species, protection by melatonin. Curr. Mol. Med. 2001, 1, 501-513.

3. Bhattacharjee, M.; Bhattacharjee, S.; Gupta, A.; Banerjee, R.K. Critical role of an endogenous gastric peroxidase in controlling oxidative damage in $\mathrm{H}$. pylori-mediated and non-mediated gastric ulcer. Free Radical. Biol. Med. 2002, 32, 731-743.

4. Konturek, P.C.; Konturek, S. Role of Helicobacter pylori infection in gastro-duodenal secretion and in pathogenesis of peptic ulcer and gastritis. J. Physiol. Pharmacol. 1994, 45, 333-350.

5. Wallace, J.L., Granger, D.N. The cellular and molecular basis of gastric mucosal defense. FASEB. J. 1996, 10, 731-740.

6. Rao, C.H.V.; Ojha, S.K.; Radhakrishnan, K.; Govindarajan, R.; Rastogi, S.; Mehrotra, S.; Pushpangadan, P. Antiulcer activity of Utleria salicifolia rhizome extract. J. Ethnopharmacol. 2004, 91, 243-249.

7. Bandyopadhyay, D.; Biswas, K.; Bhattacharyya, M.; Reiter, R.J.; Banerjee, R.K. Involvement of reactive oxygen species in gastric ulceration, protection by melatonin. Indian J. Exp. Biol. 2002, 40, 693-705.

8. Lehne RA. Pharmacology for Nursing Care; W.B. Saunders: Philadelphia, PA, USA, 1998.

9. Mota, K.S.; Dias, G.E.; Pinto, M.E., Luiz-Ferreira, A.; Souza-Brito, A.R.; Hiruma-Lima, C.A.; Barbosa-Filho, J.M.; Batista, L.M. Flavonoids with gastroprotective activity. Molecules 2009, 14, 979-1012.

10. Cechinel-Filho, V.; Yunes, R.A. Plantas medicinais sob a ótica da química medicinal moderna; Yunes, R.A., Calixto, J.B., Eds.; Argos Editora Universitária: Chapecó, Brazil, 2001.

11. Schmeda-Hirschmann, G.; Yesilada, E. Traditional medicine and gastroprotective crude drugs. $J$ Ethnopharmacol 2005, 22, 61-66. 
12. Silva, E.M.; Hiruma-Lima, C.A.; Lólis, S.F. Etnobotânica no município de Porto Nacional. In Symposium of Brazilian Medicinal Plants, Cuiabá, Brazil, 17-20 October 2000, abstract 106.

13. Siqueira, J.C. Plantas Medicinais: identificação e uso das espécies do cerrado; Loyola: São Paulo, Brazil, 1988.

14. de Almeida, S.P.; Proença, C.E.B.; Sano, S.M.; Ribeiro, J.F. Cerrado: espécies vegetais úteis; Embrapa: Brasília, Brazil, 1998.

15. Luiz-Ferreira, A.; Cola-Miranda, M.; Barbastefano, V.; Hiruma-Lima, C.A.; Vilegas, W.; Souza Brito, A.R. Should Anacardium humile St. Hil be used as an antiulcer agent? A scientific approach to the traditional knowledge. Fitoterapia 2008, 79, 207-209.

16. Raskin, I.; Ripoll, C. Can an apple a day keep the doctor away? Curr. Pharm. Des. 2004, 10, 3419-3429.

17. Sannomiya, M.; Fonseca, V.B.; da Silva, M.A.; Rocha, L.R.; Dos Santos, L.C.; Hiruma-Lima, C.A. Flavonoids and antiulcerogenic activity from Byrsonima crassa leaves extracts. J. Ethnopharmacol. 2005, 10, 1-6.

18. Nardini, N.; Leonardi, F.; Scaccini, C.; Virgili, F. Modulation of ceramide-induced NFkappa binding activity and apoptotic response by caffeic acid in U937 cells: Comparison with other antioxidants. Free Radic. Biol. Med. 2001, 30, 722-733.

19. Arisawa, T.; Shibata, T.; Kamiya, Y.; Nagasaka, M.; Nakamura, M.; Fujita, H. Effects of sucralfate, cimetidine and rabeprazole on mucosal hydroxyproline content in healing of ethanol/HCl-induced gastric lesions. Clin. Exp. Pharmacol. Physiol. 2006, 33, 628-632.

20. Morimoto, Y.; Shimohara, K.; Oshima, S.; Sukamoto, T. Effects of the new anti-ulcer agent KB5492 on experimental gastric mucosal lesions and gastric mucosal defensive factors, as compared to those of teprenone and cimetidine. Jpn. J. Pharmacol. 1991, 57, 495-505.

21. Ham, M.; Kaunitz, J.D. Gastroduodenal defense. Curr. Opin. Gastroenterol. 2007, 23, 607-616.

22. Laine, L.; Takeuchi, K.; Tarnawski, A. Gastric mucosal defense and cytoprotection: Bench to bedside. Gastroenterology 2008, 135, 41-60.

23. Allen, A.; Flemström, G. Gastroduodenal mucus bicarbonate barrier: Protection against acid and pepsin. Am. J. Physiol. Cell Physiol. 2005, 288, C1-C19.

24. Laine, L.; Weinstein, W.M. Histology of alcoholic hemorrhagic "gastritis" a prospective evaluation. Gastroenterology, 1988, 94, 1254-1262.

25. Qui, B.S.; Mei, Q.B.; Liu, L.; Tchou-Wong, K.M. Effects of nitric oxide on gastric ulceration induced by nicotine and cold-restraint stress. World J. Gastroenterol. 2004, 10, 594-597.

26. Khattab, M.M.; Gad, M.Z.; Abdallah, D. Protective role of nitric oxide in indomethacin-induced gastric ulceration by a mechanism independent of gastric acid secretion. Pharmacol. Res. 2001, 43, 463-467.

27. Elliott, S.N.; Wallace, J.L. Nitric oxide: A regulator of mucosal defense and injury. J. Gastroenterol. 1998, 33, 792-803.

28. Brzozowski, T.; Konturek, S.J.; Sliwowski, Z.; Drozdowicz, D.; Zaczek, M.; Kedra D. Role of Larginine, a substrate for nitric oxide-synthase, in gastroprotection and ulcer healing. $J$. Gastroenterol. 1997, 32, 442-452. 
29. Tariq, M.; Khan, H.A.; Elfaki, I.; Arshaduddin, M.; Al Moutaery, M.; Al Rayes, H.; Al Swailam, R. Gastric antisecretory and antiulcer effects of simvastatin in rats. J. Gastroenterol. Hepatol. 2007, 22, 2316-2323.

30. Petersson, J.; Phillipson, M.; Jansson, E. A.; Patzak, A.; Lundberg, J. O.; Holm, L. Dietary nitrate increases gastric mucosal blood flow and mucosal defense. Am. J. Physiol. Gastrointest. Liver Physiol. 2007, 292, 718-724.

31. La Casa, C.; Villegas, I.; Alarcón de la Lastra, C.; Motilva, V.; Martín Calero, M.J. Evidence for protective and antioxidant properties of rutin, a natural flavone, against ethanol-induced gastric lesions. J. Ethnopharmacol. 2000, 71, 45-53.

32. Hiraishi, H.; Terano, A.; Ota, S.; Mutoh, H.; Sugimoto, T.; Harada, T.; Razandi, M. Protection of cultured rat gastric cells against oxidant induced damage by exogenous glutathione. Gastroenterology 1994, 106, 1199-1207.

33. Hernandez-Munoz, R.; Montiel-Ruíz, C.; Vázquez-Martínez, O. Gastric mucosal cell proliferation in ethanol-induced chronic mucosal injury is related to oxidative stress and lipid peroxidation in rats. Lab. Invest. 2000, 80, 1161-1169.

34. Wagner, H.; Bladt, S.; Zgainski, E.M. Plant drug analysis a thin layer chromatography atlas; Springer-Verlag: Berlin, Germany, 1984.

35. Agrawal, P.K. Carbon-13 NMR of flavonoids; Elsevier: New York, NY, USA, 1989.

36. Harborne, J.B. The Flavonoids advances in research since 1986; Chapman \& Hall: London, UK, 1994.

37. Szelenyi, I.; Thiemer, K. Distention ulcer as a model for testing of drugs for ulcerogenic side effects. Arch. Toxicol. 1978, 41, 99-105.

38. Curtis, G.H.; MacNaughton, W.K.; Gall, D.G.; Wallace, J.L. Intraluminal pH modulates gastric prostaglandin synthesis. Can. J. Physiol. Pharmacol. 1995, 73, 130-134.

39. Rafatullah, S.; Tariq, M.; Al-Yahya, M.A.; Mossa, J.S.; Ageel, A.M. Evaluation of turmeric (Curcuma longa) for gastric and duodenal antiulcer activity in rats. J. Ethnopharmacol. 1990, 29, 25-34.

40. Arrieta, J.; Benitez, J, Flores, E.; Castilho, C.; Navarrete, A. Purification of gastroprotective triterpenoids from stem bark of Amphipterygium adstringens; roles of prostaglandins, sulphidryls, nitric oxide and capsaicin neurons. Planta Med. 2003, 69, 905-909.

41. Behmer, O.A.; Tolosa, E.M.C.; Freitas Neto, A.G. Manual de técnicas para histologia normal e patológica; EDART: São Paulo, Brazil, 1976.

42. Vacca, L.L. Laboratory Manual of Histochemistry; Raven Press: New York, NY, USA, 1985.

Sample Availability: Samples of the compounds are available from the authors.

(C) 2010 by the authors; licensee MDPI, Basel, Switzerland. This article is an open access article distributed under the terms and conditions of the Creative Commons Attribution license (http://creativecommons.org/licenses/by/3.0/). 